Удк 004.94:621.316

DOI https://doi.org/10.32851/tnv-tech.2021.3.2

\title{
ІНФОРМАЦІЙНО-МОДЕЛЮЮЧА СИСТЕМА АНАЛІЗУ ПРОЦЕСУ ЦІНОУТВОРЕННЯ НА РИНКУ ЕЛЕКТРИЧНОЇ ЕНЕРГІЇ
}

\author{
Євдокімов В.А. - кандидат наук з державного управління, \\ провідний науковий співробітник \\ Інституту проблем моделювання в енергетиці імені Г.Є. Пухова \\ Національної академії наук України \\ ORCID ID: 0000-0001-9497-4030
}

У статті розглянуто призначення, функиіональні особливості та можливості розробленої інформачійно-моделюючої системи аналізу прочесу ціноутворення на ринку електричної енергії, яка відображає складний динамічний процес иіноутворення та надає агентам-учасникам ринку можливість організації прозорої децентралізованої взаємодії. Головним призначенням системи є надання і постачальникам, і виробникам електричної енергї інформації щуодо формування стратегії своєї поведінки на ринку в напрямі досягнення балансу як власних, так і суспільних інтересів, та можливість використання системи імітаційних моделей та моделюючих алгоритмів для рішення розрахункових задач формування торгових заявок для участі в аукиіонах купівлі-продажу електроенергії. Такий підхід надає можливість досягнути синергетичного ефекту за рахунок неперервного прозорого врахування взаємного впливу бізнес-інтересів різних учасників, які одночасно беруть участь у прочесі иіноутворення. Інформачійно-моделююча система $\epsilon$ імітаційною системою та об'єктом, у склад функціональних структурних елементів якого входять: комплекс імітаційних моделей сегментів ринку та моделей короткострокового (на добу наперед) прогнозу иін; моделюючі алгоритми розрахунку ичінових показників на різних сегментах ринку та програмні засоби їх реалізацї; моделюючі алгоритми та програмні засоби рішення задач урахування впливу факторів ризику на иіноутворення (динаміка иін на енергоносї тощзо); бази даних та відповідної СУБД; засоби, які забезпечують організацію роботи інформачійно-моделюючої системи, інтерфейси адміністратора для актуалізаиії верифікованої інформаиії бази даних та інтерфейси користувачів для організачії роботі з моделями, моделюючими алгоритмами і базою даних. Метою створення системи є підвищення ефективності й оперативності функиіонування агентів ринку під час формування заявок на участь у проведенні торгів. В основу розробки інформаиійно-моделюючої системи закладено застосування принципів мультиагентного підходу для організації інформаційно-технологічної взаємодії агентів ринку між собою $і$ зовніинім середовищем - реально діючою інформаційно-технологічною інфраструктурою ринку та створення інформаційно-технологічного та методичного мультиагентного середовища, в якому агенти ринку взаємодіють і конкурують на різних сегментах ринку електричної енергії. На основі проведеного дослідження наукової літератури обтрунтовано необхідність побудови такого класу системи, яка є складовою частиною програмно-апаратного комплексу імітаційної системи иіноутворення на оптовому та роздрібному ринку електричної енергї̈ на основі сучасних інформаційних технологій. Наведено короткий опис системи.

Ключові слова: агент, інформаційно-моделююча система, мультиагентне середовище, ринок електричної енергії, ичноутворення.

Evdokimov V.A. Information and modeling system for analysis of the pricing process in the electricity market

The article considers the purpose, functional features and capabilities of the developed information and modeling system for analyzing the pricing process in the electricity market, which reflects the complex dynamic pricing process and gives market participants the opportunity to organize transparent decentralized interaction. The main purpose of the system is to provide both suppliers and producers of electricity, information on the formation of strategies for their behavior in the market to achieve a balance of both personal and public interests, and the ability to use a system of simulation models and modeling algorithms to solve calculation problems to participate in auctions of purchase and sale of electricity. This approach provides an opportunity 
to achieve a synergistic effect, through continuous transparent consideration of the mutual influence of business interests of different participants who are simultaneously involved in the pricing process. The information-modeling system is a simulation system and object, the functional structural elements of which include: a set of simulation models of market segments, and models of short-term (day ahead) price forecast; modeling algorithms for calculating price indicators in different market segments and software for their implementation; modeling algorithms and software for solving problems of taking into account the influence of risk factors on pricing (dynamics of energy prices, etc.); database and corresponding DBMS; tools that provide the organization of the information modeling system, administrator interfaces for updating the database with verified information and user interfaces for organizing work with models, modeling algorithms and database. The purpose of the system is to increase the efficiency and effectiveness of market agents in the formation of applications for participation in the auction. The development of the information-modeling system is based on the application of the principles of multi-agent approach to the organization of information-technological interaction of market agents between themselves and the external environment - the real information-technological infrastructure of the market, and the creation of information-technological and methodical multi-agent environment in which market agents interact and compete in different segments of the electricity market. Based on the study of scientific literature, the need to build such a class of system, which is part of the software and hardware of the simulation system of pricing in the wholesale and retail electricity market based on modern information technology. A brief description of the system is given.

Key words: agent, information modeling system, multiagent environment, electricity market, pricing.

Вступ. У роботах [1-2] розглянуто і сформульовано основні теоретичні та прикладні задачі вдосконалення методів і засобів математичного й комп'ютерного моделювання процесів інформаційно-технологічної взаємодії між учасниками ринку електричної енергії, а також принципи побудови мультиагентної імітаційної моделі процесів ціноутворення на ринку електричної енергії. Там же обгрунтовано актуальність і необхідність створення інформаційно-моделюючої системи (далі - IMC) процесу ціноутворення на ринку електричної енергії як системи інформаційного та розрахунково-технологічного забезпечення агентів ринку під час вирішення ними функціональних завдань у межах визначених стратегій поведінки задля досягнення цілей та інтересів за допомогою відповідного модельного та алгоритмічного інструментарію. Метою розроблення та впровадження такого інструментарію є підвищення продуктивності процесу прийняття рішень учасниками в підготовці та формуванні торгових заявок купівлі-продажу електроенергії на конкурентних сегментах ринку.

Постановка завдання. В Україні впроваджено нову модель ринку електричної енергії, яку побудовано з дотриманням вимог загальновідомої в наукової літературі під назвою «Конкуренція на всіх рівнях». У результаті склалася більш складна система взаємовідносин між учасниками як на ринку в цілому, так і в новоутворених його сегментах: ринок двосторонніх договорів (РДД); ринок «на добу наперед» (РДН); внутрішньодобовий ринок (ВДР); балансуючий ринок (БР), роздрібний ринок (РP). Але така багатосегментна структура ринку надає можливість усім його учасникам реально конкурувати між собою, а також вільно вибирати як постачальника, так і виробника електричної енергії.

Наприклад, на роздрібному ринку кардинально змінюється система взаємовідносин унаслідок появи нових учасників - постачальників електричної енергії, постачальників універсальних послуг, операторів системи розподілу, які займаються розподілом електричної енергії, а також відповідають за іiї комерційний облік. Ринок зараз працює за новими правилами, відповідно до яких формування тарифів для кінцевого споживача буде залежати не тільки від його поведінки, оскільки саме він визначає обсяги попиту в залежності від тарифів, а ще 
й від витрат за послуги за постачання електричної енергії - тарифів, умов оплати й обсягу продукції, що постачається. Конкуренція на цьому сегменті ринку буде залежати від стратегії надання послуг з постачання електричної енергії постачальними компаніями, енерготрейдерами, які будуть мати можливість здійснювати планування обсягів споживання на основі застосування якісних моделей прогнозування зміни цін на сегментах ринку та необхідних обсягів електричної енергії для безумовного покриття затребуваної споживачем енергії.

Отже, для ефективної роботи на зазначених сегментах ринку необхідний не тільки досвід, але й інструментарій - модельний та алгоритмічний, програмне забезпечення, яке дозволить учасникам сегментів ринку здійснювати необхідні прогнозні розрахунки, а також за допомогою моделей надасть можливість проаналізувати ступінь ризикованості поведінки на цих сегментах та пошуку найбільш раціональних та ефективних сценаріїв реалізації вибраної стратегії. Тому й була поставлена задача побудови IMC як імітаційної системи, яка була би гнучким інформаційно-технологічним інструментом комплексного прогнозу та аналізу наслідків діяльності учасників ринку електричної енергії, призначеним для дослідження процесів ціноутворення в нової моделі ринку та пошуку найбільш раціональних шляхів еволюційного розвитку конкурентних взаємовідносин учасників-агентів на оптовому та роздрібному ринках.

Мета дослідження. Основною метою створення IMC є підвищення ефективності й оперативності функціонування агентів під час формування заявок на участь у проведенні торгів на лібералізованому ринку електричної енергії, які формуються з урахуванням визначених оптимальних 3 точки зору агентів стратегій. Задля досягнення цієї мети необхідно розробити інструментарій модельний та алгоритмічний, програмне забезпечення із застосуванням засобів алгоритмічного моделювання процесів формування показників цін, обсягів у заявках від агентів в умовах конкурентного відбору пропозицій виробників та постачальників.

Аналіз останніх досліджень і публікацій. Сформульовану задачу можна віднести до класу задач удосконалення системи організаційного управління (далі СОУ) ринком електроенергії. Тому багато фахівців пов'язують підвищення продуктивності рішення задач організаційного управління конкурентними ринками з розвитком досліджень проблеми вдосконалення методів і засобів математичного і комп'ютерного моделювання процесів прийняття рішень щодо розроблення нових або вдосконалення діючих регуляторних механізмів функціонування ринків і створення на їхній основі якісно нових СОУ.

Серед проблем створення СОУ є такі: висока вартість упровадження моделі ринку, складна структура розподілу ринку на його сегменти, неминуча волатильність та маніпулювання спотовими цінами, маніпулювання окремими гравцями, здійснюване ринковою владою, складність зниження вартості генерації, непередбачуваність цін на ринках енергоресурсів, неокупність вартості виробництва електричної енергії частиною генеруючих потужностей, нерівний розподіл доходів від реалізації спільно виробленої і поставленої споживачам продукції [2].

Представлена в даній статті IMC згідно з відомою класифікацією є фактично системою підтримки прийняття рішень (далі - СППР) щодо функціонування агентів на ринку електричної енергії [3-8]. Як показує далеко не повний огляд праць, присвячених проектуванню та побудові СППР в різних предметних областях застосування, з моменту початку використання такого словосполучення в науковій літературі, за даними сайту [9], опубліковано тисячі наукових робіт. Тому 
зупинимося на аналізі лише тих праць, дослідження в яких присвячені побудові імітаційних моделей для формування заявок учасниками ринку і використовуються як СППР.

У роботі [10] проведено аналіз світового досвіду функціонування конкурентних ринків електроенергії в частки використання способів подання заявок учасників ринків РДН та БР. Встановлено, що існує два основних підходи щодо подання заявок купівлі-продажу ЕЕ. Перший підхід, в якому в заявках використовуються «поетапні ціново-кількісні пари», застосовують генеруючі компанії на ринках Іспанії, Італії, Нідерландів, Польщі та Румунії. Другий підхід, в якому в заявках використовуються подання «дискретних ціново-кількісних пар з лінійною інтерполяцією по між ними», застосовується на біржах EE NordPool, в Німеччині, Франції [10]. Там же детальніше описано особливості використання цих підходів.

Проведений аналіз літературних джерел [11-18] показує, що для формування заявок знаходять застосування різні імітаційні моделі сегментів ринку з метою пошуку оптимальних рішень для подачі заявок з купівлі-продажу електроенергії, а також моделі процесів ціноутворення на них. Чимало досліджень присвячено вдосконаленню методів прогнозування цінових показників функціонування ринку. Природно, що перераховані інструментальні засоби з різним ступенем продуктивності можуть бути використані й використовуються як СППР.

Незважаючи на наявність на ринку досить великої кількості комп'ютерних систем моделювання, які використовуються для побудови імітаційних моделей процесів ціноутворення, можна стверджувати, що в найближчі роки навряд чи 3'явиться універсальне програмне забезпечення, що реалізує імітаційні моделі процесів функціонування складних багаторівневих СОУ ринком електроенергії, яке можна було б адаптувати та використовувати для всіх систем такого класу складності. Тому багато досліджень у науковій літературі присвячено проблемі подальшого вдосконалення імітаційних моделей і систем, які використовуються як СППР у вирішенні завдань організаційного управління ринком електроенергії.

Виходячи з поставлених цілей даної роботи та враховуючи специфіку предметної області - ринку електричної енергії, інформаційна технологія побудови IMC функціонально повинна відповідати таким сучасним вимогам [5-8; 19], як:

- підтримка розподіленої в просторі архітектури системи;

- підтримка корпоративної нормативно-довідкової інформації;

- наявність механізмів обміну інформацією, що зберігається на різних рівнях управління;

- модульний принцип побудови, що допускає ізольоване використання окремих компонент системи, а також їхніх комбінацій, що диктуються виробничо-економічними завданнями;

- можливість агрегування, консолідації та інтеграції даних за рівнями управління;

- забезпечення інтерфейсів взаємодії із зовнішніми системами;

- можливість нарощування функціонального складу системи.

Крім того, вона повинна враховувати ретроспективні (за весь період функціонування діючої моделі ринку) дані про ключові параметри функціонування ринку та мати необхідні засоби для прогнозування майбутніх цін і обсягів споживання електричної енергії на ринку, а також за допомогою відповідних алгоритмів формування цін та тарифів надавати можливість користувачам побудувати моделі для розрахунку цін, зокрема на таких сегментах, як РДН та БР. 
Виклад основного матеріалу дослідження. Структурно IMC складається із 4-х основних функціональних блоків, пов'язаних зі здійсненням збору, обробкою динамічних і статистичних даних та проведенням процесів ціноутворення прогнозування і моделювання учасників ринку електричної енергії, а саме таких, як:

1) «База (банк) даних ринку електричної енергії». Зазначений блок використовується адміністратором системи, який забезпечує в автоматичному режимі збір та обробку динамічних і статистичних даних в IMC;

2) «Актуальна інформація стану ринку електричної енергії». Цей блок дозволяє візуально спостерігати за станом інформації ринку електричної енергії в залежності від сегментів ринку (оптовий та роздрібний ринок), його як цінові, так і технічні показники, а також здійснювати відповідний моніторинг та аналіз, використовуючи можливість скачування актуальної інформації із IMC;

3) «Прогнозування». Цей блок дозволяє здійснювати прогнозування як погодинних, так і місячних даних цін та обсягів на відповідних сегментах ринку з використанням моделі штучних нейронних мереж та інших моделей;

4) «Моделювання». Зазначений блок надає можливість здійснювати різні сценарні поведінки учасників ринку електричної енергії з метою отримання відповідних цілей та завдань. Для цього пропонується вносити відповідні змінні дані обсягів, цін та термінів виробництва/постачання/ споживання, що у свою чергу впливають на кінцеву ціну відповідного сегменту ринку (оптового та роздрібного ринку).

Додомо, що база даних IMC дозволяє діючим учасникам ринку, а також майбутнім активним споживачам електроенергії, визначити обсяги та ціни на відповідних сегментах ринку електричної енергії, зокрема на ринку двосторонніх договорів, ринку «на добу наперед» та внутрішньодобовому ринку, балансуючому ринку та роздрібному ринку. При цьому в ній передбачено можливість урахування:

- тарифу на послугу з передачі електричної енергії магістральними мережами;

- тарифу на розподіл електричної енергії місцевими локальними мережами;

- тарифів на постачання електричної енергії постачальниками універсальних послуг;

- тарифу з диспетчерського управління й цін і тарифів на інші послуги.

На основі даних результатів конкурентного відбору система дозволяє визначати перелік блоків ТЕС виробників, пропозиції яких акцептуються на ринку двосторонніх договорів, ринку «на добу наперед», балансуючому ринку для усунення небалансу в системі та врахування системних обмежень, а також ціни за небаланси для сторін, відповідальних за баланс. Результати розрахунків можна переглядати в графічному та табличному вигляді.

Система збору даних IMC формує та актуалізує базовий набір вхідних даних, який дозволяє користувачеві на першому етапі отримати певні результати розрахунків поточного стану ринку в показниках складників ціни у споживача.

На наступних етапах надається можливість:

- здійснювати оціночні розрахунки із внесенням власних вхідних даних для погодинного прогнозування цін за допомогою нейросіткової моделі для різних варіантів показників стану ринку;

- проводити прогнозні розрахунки цін і тарифів, ураховуючи в процесі розрахунку дані інших користувачів, що створює ефект онлайн-гри;

- формувати різниці цін споживача в діючому ринку та отриманої за результатами оціночних розрахунків. 
Підвищення ефективності й оперативності функціонування агентів досягається за рахунок того, що в IMC автоматизовано такі розрахунково-технологічні процеси:

- здійснення аналізу поведінки учасників в умовах діючої моделі ринку, зокрема визначати перелік генеруючого устаткування, яке може бути включене в роботу, за результатами моделювання процесу конкурентного відбору пропозицій виробників на ринку «на добу наперед» та балансуючому ринку;

- збирання та візуалізації інформації про функціонування ринку електроенергії у зручній єдиній формі для виробників, постачальників, споживачів, підприємств системи передачі електроенергії та диспетчерського управління задля здійснення зрівняльного аналізу цін та тарифів;

- зберігання бази даних кінцевих споживачів з урахуванням регіону постачання та класу напруги мереж, до яких підключений споживач, що забезпечить підвищення точності та актуальності даних під час проведення моделюючих розрахунків для всіх користувачів системи;

- здійснення оцінки мінімально-можливих цін та тарифів, виходячи 3 витрат, які можуть бути понесені учасниками ринку електричної енергії та визначення мінімальної ціни в кінцевого споживача в нових умовах організаційної і технологічної взаємодії учасників ринку відповідно до його Правил [20-22];

- обслуговування процесів підготовки торгів на ринку «на добу наперед» та «внутрішньодобовому» ринку для забезпечення виконання ключових функцій із прийому і зберігання технічної та комерційної інформації, яка надається учасниками ринку, обробка оперативних даних учасників ринку, моніторинг динаміки показників сегментів ринків та аналіз поведінки ії учасників;

- ведення нормативних документів у частині діючих тарифів, витрат на передачу електроенергії магістральними мережами, її розподіл;

- накопичення поточної інформації від виробників, постачальників, споживачів електричної енергії в частині обсягів виробництва та відпуску електроенергії, постачання електроенергії споживачам, обсягів утрат електроенергії, заявок та обмежень за потужністю виробників;

- накопичення та зберігання результатів розрахунків обсягів купівлі-продажу електроенергії, середньозважених цін на електроенергію, аналітико-статистичних та прогнозних розрахунків.

Висновки та пропозиції. Розроблено та побудовано (на момент виходу статті) інформаційно-моделюючу систему як складову частину відкритої комплексної моделюючої системи ціноутворення на оптовому та роздрібному ринку електричної енергії (https://equant.pp.ua). Розвиток та іï вдосконалення буде проводитись шляхом запровадження нових комп'ютерних моделей функціонування сегментів ринку, впливу факторів ризику, підвищення якості моделей прогнозування основних показників ринку електричної енергії. Крім того, в результаті проведення необхідних процедур сценарного аналізу на основі статистичних даних динаміки поведінки цих різних груп учасників ринку електричної енергії стане можливим визначити, аналізувати та оцінювати основні фактори ризику в прийнятті рішень і на цій основі сформувати пропозиції щодо корегування стратегії подальшого розвитку самого ринку, а також його окремих сегментів.

\section{СПИСОК ВИКОРИСТАНОӤ ЛІТЕРАТУРИ:}

1. Мохор В.В., Євдокімов В.А. Про створення мультиагентної імітаційної моделі процесів ціноутворення на ринку електроенергії. Електрон. Моделювання. 2020. № 6. С. 3-17. 
2. Євдокімов В.А. Формулювання задачі побудови мультиагентної імітаційної моделі процесів ціноутворення на ринку електроенергії. Електрон. Моделювання. 2021. № 3. C. 1-16.

3. Eom S.B. Decision support systems research: current state and trends. Industrial Management \& Data Systems. 1999. Vol. 99/5/ P. 213-220.

4. Eom S.B. DSS, BI, and Data Analytics Research: Current State and Emerging Trends (2015-2019). Decision Support Systems X: Cognitive Decision Support Systems and Technologies. Springer International Publishing, 2020. P. 167-179.

5. Ларичев О.И., Петровский А.Б. Системы поддержки принятия решений: современное состояние и перспективы развития. Итоги науки и техники: Техническая кибернетика. Москва : ВИНИТИ, 1987. Т. 21. С. 131-164.

6. Трахтенгерц Э.А. Компьютерные системы поддержки принятия управленческих решений. Информационные технологии в управлении: Проблемы управления. 2003. № 1. C. 13-28.

7. Концепция построения информационно-технологической платформы проектирования систем поддержки принятия решений для организационного управления энергорынком. Адаптивні системи автоматичного управління / 3.X. Борукаев и др. 2018. № 1 (32). С. 3-14.

8. Тиханычев О.В. Теория и практика автоматизации поддержки принятия решений. Москва : Эдитус, 2018. 76 с.

9. URL: https://www.elibrary.ru/title_items.asp?id=10431

10. Блінов I.В., Парус Є.В. Підхід до формування лотів виробників на аукціоні 3 купівлі-продажу електричної енергії. Праці Інституту електродинаміки НАН України. Київ : ІЕД НАНУ, 2011. Вип. 28. С. 20-25.

11. Королев М., Углов Д. Составляем заявки на продажу. Профессиональный журнал. 2004. С. 64-69.

12. Выбор оптимальной стратегии поведения генерирующей компании на рынке «на сутки вперед» в условиях рыночного регулирования. Вектор науки ТГУ / А.Ю. Амелина и др. 2013. № 4. С. 63-68.

13. Микешина А.А. Стратегия поведения генерирующей компании на оптовом рынке электроэнергии. Экономика, Статистика и Информатика. 2010. № 6. C. $190-192$.

14. Филатов С.А. Модели и методы формирования оптимальных стратегий поведения генерирующих компаний на оптовом рынке электрической энергии : автореф. дисс. ... канд. экон. наук : 08.00.13. Санкт-Петербург : из-во СПб ГИЭУ, 2014. 19 c.

15. Математическая модель управления функционированием генерирующей компании в современных условиях. Известия Томского политехнического университета. Инжиниринг георесурсов / Ю.А. Секретарев м др. 2018. Т. 329. № 2. C. $146-158$.

16. Битеряков Ю.Ф., Кутинов С.А. К вопросу формирования цен на конкурентных рынках электроэнергии. Вестник ИГЭУ. 2005. Вып. 2. С. 1-4.

17. Балансуючий ринок електроенергії України та його математична модель. Технічна електродинаміка / О.В. Кириленко та ін. 2011. № 2. С. 36-43.

18. Імітаційна модель ринку електричної енергії «на добу наперед» 3 неявним урахуванням мережевих обмежень енергетичних систем. Техн. електродинаміка / О.В. Кириленко та ін. 2019. № 5. С. 60-67. DOI: https://doi.org/10.15407/ techned2019.05.060

19. Сараев А.Д, Щербина О.А. Системный анализ и современные информационные технологи. Труды Крымской Академии наук. Симферополь (Симферополь-Вена) : СОНАТ, 2006. С. 47-59.

20. Національна комісія, що здійснює державне регулювання у сферах енергетики і комунальних послуг. Про затвердження Правил ринку. Постанова № 307 
від 14.03.2018 p. URL: https://zakon.rada.gov.ua/laws/show/v0307874-18\#Text (дата звернення: 06.07.21).

21. Національна комісія, що здійснює державне регулювання у сферах енергетики і комунальних послуг. Про затвердження Правил ринку «на добу наперед» та внутрішньодобового ринку. Постанова № 308 від 14.03.2018 p. URL: https:// zakon.rada.gov.ua/laws/show/v0308874-18\#Text (дата звернення: 06.07.21).

22. Національна комісія, що здійснює державне регулювання у сферах енергетики і комунальних послуг. Про затвердження Правил роздрібного ринку. Постанова № 312 від 14.03.2018 p. URL: https://zakon.rada.gov.ua/laws/show/ v0312874-18\#Text (дата звернення: 06.07.21).

\section{REFERENCES:}

1. Mohor V.V. (2020) On the creation of a multi-agent simulation model of pricing processes in the electricity market / V.V. Mohor, W.A. Evdokimov // Electron. modeling, 42, № 6, 3-17.

2. Evdokimov V.A. (2021) Formulation of the problem of building a multi-agent simulation model of pricing processes in the electricity market / V.A. Evdokimov // Electron. modeling, 43, № 3, 1-16.

3. Eom S.B. (1999) Decision support systems research: current state and trends // Industrial Management \& Data Systems, vol. 99/5, 213-220.

4. Eom S.B. (2020) DSS, BI, and Data Analytics Research: Current State and Emerging Trends (2015-2019) // Decision Support Systems X: Cognitive Decision Support Systems and Technologies. Springer International Publishing, pp. 167-179.

5. Larichev O.I., Petrovsky A.B. (1987) Decision support systems: current status and development prospects // Results of science and technology: Technical cybernetics. M.: VINITI, t. 21, 131-164.

6. Trachtengertz E.A. (2003) Computer systems to support management decisionmaking // Information technology in management: Management problems, № 1, 13-28.

7. Borukaev Z.H. (2018) The concept of building an information technology platform for designing decision support systems for organizational management of the energy market / Z.H. Borukaev, K.B. Ostapchenko, O.I. Lisovichenko // Adaptive automatic control systems, № 1 (32), 3-14.

8. Tihanichev O.V. (2018) Theory and practice of automation of decision support. M.: Edits., 76 p.

9. https://www.elibrary.ru/title_items.asp?id $=10431$

10. Blinov I.V. (2011) The approach to the formation of lots of manufacturers at the auction for the purchase and sale of electricity / I.V. Blinov, E.V. Parus // Proceedings of the Institute of Electrodynamics of the National Academy of Sciences of Ukraine. - K.: IED NASU, Issue 28, 20-25.

11. Korolev M. (2004) We make applications for sale... / M. Korolev, D. Uglov // Professional magazine, 64-69.

12. Amelina A.Yu. (2013) The choice of the optimal strategy of the behavior of the generating company in the market "a day ahead" in terms of market regulation / A.Yu. Amelina, E.M. Lisin, Yu.A. Anisimova, V. Strielkovski // Vector of science of TSU, 2013,№ 4, 63-68.

13. Mikeshina A.A. (2010) Strategy of behavior of the generating company in the wholesale electricity market / A.A. Mikeshina // Economics, Statistics and Informatics, № 6, 190-192.

14. Filatov S.A. (2014) Models and methods of formation of optimal strategies of behavior of generating companies in the wholesale electricity market: author's ref. diss. ... Cand. econ. Science: 08.00.13 / S.A. Filatov. - St. Petersburg: from St. Petersburg GIEU, 19 p. 
15. Sekretarev Yu. A. (2018) Mathematical model of control of functioning of the generating company in modern conditions / Yu. A. Sekretarev, T.V. Myatezh, B.N. Moshkin // Izvestiya Tomskogo politekhnicheskogo universiteta. Georesource engineering,V. 329, № 2, 146-158.

16. Biteryakov Yu.F. (2005) On the issue of price formation in competitive electricity markets / Yu.F. Biteryakov, S.A. Kutinov // Bulletin of IGEU. -. - Issue, 1-4.

17. Kirilenко O.V. (2011) Balancing electricity market of Ukraine and its mathematical model / O.B. Kirilenко, I.B. Blinov, E.V / Sail // Technical electrodynamics, № 2, 36-43.

18. Kirilenко O.B. (2019) Simulation model of the electricity market "for the day ahead" with implicit consideration of network constraints of energy systems / O.V. Kirilenko, I.B. Blinov, EV Parus, G.A. Ivanov // Techn. electrodynamics, № 5, 60-67. DOI: https://doi.org/10.15407/techned2019.05.060

19. Saraev A.D. (2006) System analysis and modern information technologies / A.D. Saraev, O.A. Shcherbina // Proceedings of the Crimean Academy of Sciences. Simferopol (Simferopol - Vienna): SONAT. - P. 47-59.

20. National Commission for State Regulation of Energy and Utilities. About the statement of Rules of the market. Resolution № 307 of March 14, 2018 [Electronic resource]: Access mode: https://zakon.rada.gov.ua/laws/show/v0307874-18\#Text (Application date: 06.07.21).

21. National Commission for State Regulation of Energy and Utilities. On approval of the Rules of the day-ahead market and the intraday market. Resolution № 308 of March 14, 2018 [Electronic resource]: Access mode: https://zakon.rada.gov.ua/laws/ show/v0308874-18\#Text - (Application date: 06.07.21).

22. National Commission for State Regulation of Energy and Utilities. About the statement of Rules of the retail market. Resolution 12312 of March 14, 2018 [Electronic resource]: Access mode: https://zakon.rada.gov.ua/laws/show/v0312874-18\#Text. (Date of application: 06.07.21). 